\title{
Inter-Calibration of HY-1B/COCTS Thermal Infrared Channels with MetOp-A/IASI
}

\author{
Mingkun Liu ${ }^{1,2}$, Christopher J. Merchant ${ }^{2,3}$ (D), Lei Guan ${ }^{1,4, *}$ and Jonathan P. D. Mittaz ${ }^{2}$ \\ 1 Department of Marine Technology, College of Information Science and Engineering, \\ Ocean University of China, Qingdao 266100, China; liumingkun_ouc@126.com \\ 2 Department of Meteorology, University of Reading, Reading RG6 6BB, UK; \\ c.j.merchant@reading.ac.uk (C.J.M.); j.mittaz@reading.ac.uk (J.P.D.M.) \\ 3 National Centre for Earth Observation, University of Reading, Reading RG6 6BB, UK \\ 4 Laboratory for Regional Oceanography and Numerical Modeling, \\ Qingdao National Laboratory for Marine Science and Technology, Qingdao 266071, China \\ * Correspondence: leiguan@ouc.edu.cn; Tel.: +86-(0)532-66781802
}

Received: 13 June 2018; Accepted: 20 July 2018; Published: 25 July 2018

Abstract: The Chinese Ocean Color and Temperature Scanner (COCTS) on board the Haiyang-1B (HY-1B) satellite has two thermal infrared channels (9 and 10) centred near $11 \mu \mathrm{m}$ and $12 \mu \mathrm{m}$, respectively, which are intended for sea surface temperature (SST) observations. To improve the accuracy of COCTS SSTs, inter-calibration of COCTS thermal infrared radiance is carried out. The Infrared Atmospheric Sounding Interferometer (IASI) on board MetOp-A satellite is used as inter-calibration reference owing to its hyperspectral nature and high-quality measurements. The inter-calibration of HY-1B COCTS thermal infrared radiances with IASI is undertaken for data from the Period 2009-2011 located in the northwest Pacific. Collocations of COCTS radiance with IASI are identified within a temporal window of $30 \mathrm{~min}$, a spatial window of $0.12^{\circ}$ and an atmospheric path tolerance of $3 \%$. Matched IASI spectra are convolved with the COCTS spectral response functions, while COCTS pixels within the footprint of each IASI pixel are spatially averaged, thus creating matched IASI-COCTS radiance pairs that should agree well in the absence of satellite biases. The radiances of COCTS 11 and $12 \mu \mathrm{m}$ channel are lower than IASI with relatively large biases, and a strong dependence of difference on radiance in the case of $11 \mu \mathrm{m}$ channel. We used linear robust regression for four different detectors of COCTS separately to obtain the inter-calibration coefficients to correct the COCTS radiance. After correction, the mean values of COCTS 11 and $12 \mu \mathrm{m}$ channel minus IASI radiance are $-0.02 \mathrm{~mW} \mathrm{~m}^{-2} \mathrm{~cm} \mathrm{sr}^{-1}$ and $-0.01 \mathrm{~mW} \mathrm{~m}^{-2} \mathrm{~cm} \mathrm{sr}^{-1}$, respectively, with corresponding standard deviations of $0.51 \mathrm{~mW} \mathrm{~m}{ }^{-2} \mathrm{~cm} \mathrm{sr}^{-1}$ and $0.57 \mathrm{~mW} \mathrm{~m}^{-2} \mathrm{~cm} \mathrm{sr}^{-1}$. Striped noise is present in COCTS original radiance imagery associated with inconsistency among the four detectors, and inter-calibration is shown to reduce, although not eliminate, the striping. The calibration accuracy of COCTS is improved after inter-calibration, which is potentially useful for improving COCTS SST accuracy in the future.

Keywords: Chinese Ocean Color and Temperature Scanner (COCTS); Infrared Atmospheric Sounding Interferometer (IASI); satellite calibration; inter-calibration; infrared

\section{Introduction}

Satellite measurements are critical for quantifying Earth's environmental parameters, monitoring climate change and informing numerical weather prediction. Satellite calibration is fundamental to the error characteristics of derived satellite products. Calibration accuracy, stability and consistency over time are important for the retrieval quality of geophysical and atmospheric parameters [1]. 
Inter-calibration of satellite instruments is an effective way to quantify the calibration difference between a target instrument and a reference instrument, and to make the target instrument radiance closer to the reference calibration [1-3]. Thus, inter-calibration may increase the confidence in the operational calibration of individual satellites.

The Haiyang-1B (HY-1B) satellite, operated by the National Ocean Satellite Application Center (NSOAS) of the State Oceanic Administration (SOA) of China, was launched in April 2007. The satellite operated in a near sun-synchronous polar orbit at altitude of $798 \mathrm{~km}$. The main payloads on board HY-1B are the Chinese Ocean Color and Temperature Scanner (COCTS) and Coastal Zone Imager (CZI). The main objective of the HY-1B satellite is the detection of marine environmental parameters, including chlorophyll concentration, suspended sediment concentration, dissolved organic matter, pollutants, and sea surface temperature (SST) [4]. The COCTS has eight visible near infrared bands $(0.402-0.422 \mu \mathrm{m}, 0.433-0.453 \mu \mathrm{m}, 0.480-0.500 \mu \mathrm{m}, 0.510-0.530 \mu \mathrm{m}, 0.555-0.575 \mu \mathrm{m}, 0.660-0.680 \mu \mathrm{m}$, $0.730-0.770 \mu \mathrm{m}$, and $0.845-0.885 \mu \mathrm{m}$ ) for ocean colour observations and two thermal infrared bands (10.30-11.40 $\mu \mathrm{m}$ and $11.40-12.50 \mu \mathrm{m}$ ) for measuring SST, with a spatial resolution of $1.1 \mathrm{~km}$ at nadir. COCTS is a whiskbroom scanner, with four parallel detectors along-track [4].

COCTS Level 2B (L2B) SST products in the northwest Pacific were previously investigated [5]. The comparison results with buoy SST measurements gave a mean difference of $1.22^{\circ} \mathrm{C}$ and standard deviation of difference of $1.78^{\circ} \mathrm{C}$ [5]. This is much poorer than the equivalent statistics generally obtained using long-established SST sensors with similar channel specifications, which would typically give a mean difference of a few tenth of a degree and standard deviations of order $0.5^{\circ} \mathrm{C}$. Stable and accurate satellite radiance measurements are important for SST retrieval. To improve COCTS SST accuracy, inter-calibration and correction of COCTS infrared radiance is essential, and is addressed in this paper.

The Infrared Atmospheric Sounding Interferometer (IASI) is one of the payloads on board MetOp series satellites, mainly providing atmospheric emission spectra to derive humidity and temperature profiles, as well as SST, clouds, atmospheric trace constituents and land measurements [6]. The IASI on board MetOp-A was launched in 2006. IASI is a whiskbroom scanning instrument with scan angles of $\pm 48.3^{\circ}$, including 30 effective fields of view (EFOV) in total. Each EFOV consists of a $2 \times 2$ matrix of instantaneous fields of view (IFOV), each IFOV having a spatial resolution of $12 \mathrm{~km}$ near nadir [6]. IASI measures the spectral radiance in 8461 channels, covering the spectrum from $3.63 \mu \mathrm{m}\left(2760 \mathrm{~cm}^{-1}\right)$ to $15.5 \mu \mathrm{m}\left(645 \mathrm{~cm}^{-1}\right)$ with a spectral binning of $0.25 \mathrm{~cm}^{-1}$ [6,7]. Radiometric calibration of the IASI is based on views of cold space and an internal blackbody [7]. The IASI calibration has been proven to be accurate and stable. Firstly, the routine monitoring of IASI data and the validation of IASI spectral, radiometric, and geometric calibration by Centre National d'Etudes Spatiales (CNES) and European Organisation for the Exploitation of Meteorological Satellites (EUMETSAT) verify that the IASI noise and calibration accuracy is stable and within specification [7-10]. In addition, Wang et al. (2011) compared the radiance from IASI and Atmospheric Infrared Sounder (AIRS) on board Aqua using double-difference and simultaneous-nadir overpass methods. Both methods showed good agreement between IASI and AIRS radiances in the tropic and polar regions, indicating their differences are less than $0.1 \mathrm{~K}$ and there are no significant long-term changes in the IASI minus AIRS differences [11]. Due to its hyperspectral nature and high-quality radiance measurements, IASI can serve as the reference for in-orbit re-calibration of other instruments. The Global Space-based Inter-Calibration System (GSCIS) uses IASI as the reference for the inter-calibration studies of the thermal infrared channels from current meteorological sensors on geostationary satellites, such as Meteosat, GOES, MTSAT, Fengyun2, and COMS instruments [3,12-14]. Moreover, IASI data have been used in other inter-calibration studies of the sensors on board the polar-orbital satellites such as Advanced Very High Resolution Radiometer (AVHRR) [15,16], Advanced Along-Track Scanning Radiometer (AATSR) [17] and Infrared Atmospheric Sounder (IRAS) [18].

In this study, we used IASI radiance as the reference to evaluate and correct HY-1B COCTS radiance of thermal infrared channels from 2009 to 2011 in the region of $0^{\circ}-48^{\circ} \mathrm{N}$ and $100^{\circ} \mathrm{E}-148^{\circ} \mathrm{E}$. 
The data we used include the COCTS Level 1B (L1B) radiance data provided by NSOAS [19] and IASI Level 1C (L1C) radiance data provided by EUMETSAT [20]. The IASI L1C products are the geolocated, calibrated and apodized radiances, consisting of 8461 spectral samples every $0.25 \mathrm{~cm}^{-1}$ [6]. This paper is organised as follows. In Section 2, the inter-calibration method is introduced. In Section 3 , we compare the COCTS thermal infrared radiances from 11 and $12 \mu \mathrm{m}$ channel with IASI. In Section 4 , we describe the calculation of coefficients for COCTS radiance correction. In Section 5, we validate the COCTS corrected radiance. In Section 6, the post-recalibration improvement in striped noise reduction is analysed. In Section 7, the main results are summarised.

\section{Inter-Calibration Method}

\subsection{Calculation of IASI-Convolved Radiance}

IASI L1C radiance data include 8461 spectral samples in every pixel with a fixed spectral binning of $0.25 \mathrm{~cm}^{-1}$. The spectral ranges of COCTS thermal infrared spectral response functions (SRFs) for 11 and $12 \mu \mathrm{m}$ channel are 9.50-12.50 $\mu \mathrm{m}$ and 10.50-13.50 $\mu \mathrm{m}$, respectively (shown in Figure 1), both with a bin size of $0.002 \mu \mathrm{m}$. Due to the spectral resolution difference between IASI spectral radiance and COCTS SRFs, linear interpolation is used to generate COCTS spectral response value at each IASI radiance samples. Then, the IASI-convolved radiance corresponding to COCTS SRFs could be calculated using Equation (1):

$$
L_{i}=\frac{\int_{\lambda_{1}}^{\lambda_{2}} L(\lambda) S_{i}(\lambda) d \lambda}{\int_{\lambda_{1}}^{\lambda_{2}} S_{i}(\lambda) d \lambda}
$$

where subscript $i$ indicates COCTS thermal infrared channel number, $L(\lambda)$ is the IASI spectral radiance, $S_{i}(\lambda)$ is the COCTS spectral response, and $\lambda_{1}$ and $\lambda_{2}$ are COCTS bandpass boundary values.

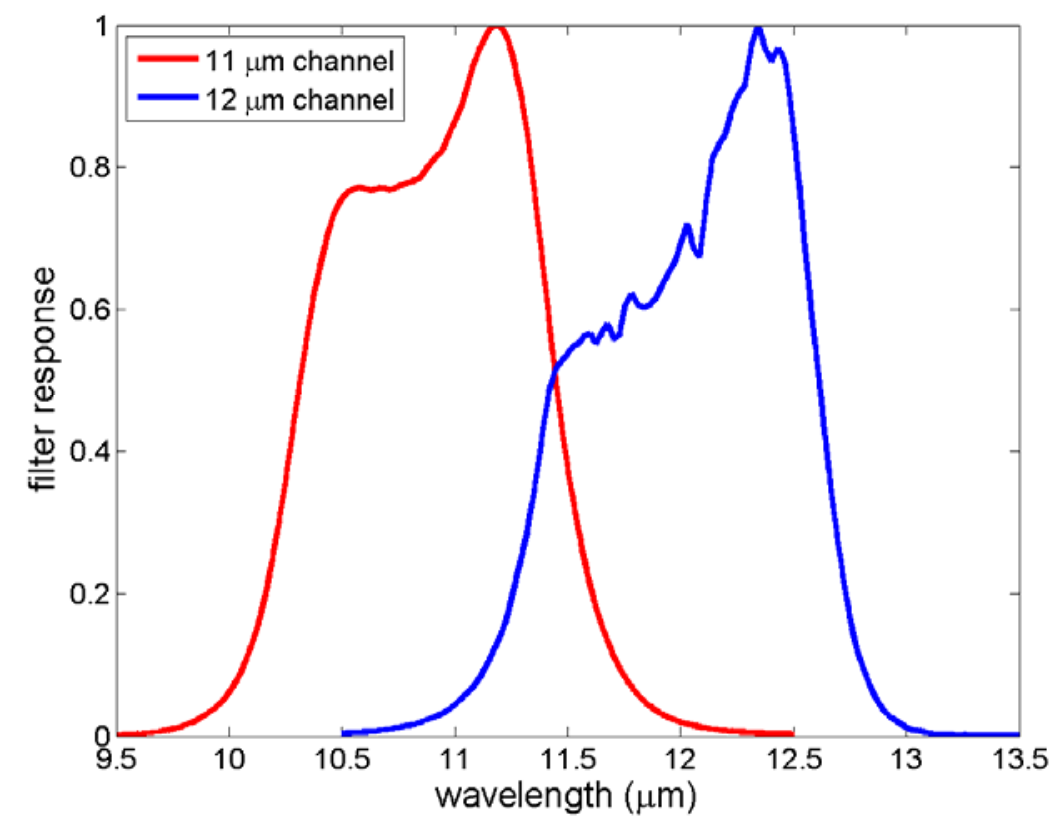

Figure 1. COCTS thermal infrared spectral response functions (SRFs) of 11 and $12 \mu \mathrm{m}$ channel.

\subsection{Generation of Matchups}

According to the COCTS and IASI spatial resolution of $1 \mathrm{~km}$ and $12 \mathrm{~km}$ near nadir, respectively, COCTS and IASI-convolved radiance are projected to equal-angle maps in the research region $\left(0^{\circ}-48^{\circ} \mathrm{N}\right.$ and $100^{\circ} \mathrm{E}-148^{\circ} \mathrm{E}$ ) with the grid size of $0.01^{\circ}$ and $0.12^{\circ}$, respectively. The collocations of COCTS and IASI radiance data are generated with a spatial window of $0.12^{\circ}$ and a temporal window of $\pm 30 \mathrm{~min}$. 
We need to ensure the matchups of COCTS and IASI are measured under similar conditions. Due to the effect of atmospheric path on radiance measurements, the satellite zenith angle of COCTS and IASI should also be matched when generating the matchup datasets. We set the threshold of difference in the secant of the satellite zenith angles as 0.03 , constraining the difference of COCTS and IASI atmospheric paths to be less than $3 \%$ to ensure the view conditions are close. The variances of COCTS minus IASI radiance difference against temporal window value and atmospheric paths difference have been checked. There is no obvious increasing trend presented, demonstrating that these window thresholds of finding collocations we set is reasonable. The radiances of COCTS pixels across all detectors inside each IASI IFOV are averaged as the collocated COCTS radiance with IASI. Typically, there are about 50-140 pixels go towards average under different satellite zenith angles. All the COCTS pixels are evenly weighted, despite the effect of IASI point spread function $[3,6]$. Considering the inconsistency between COCTS four parallel detectors, COCTS pixels inside each IASI IFOV measured by per detector are averaged separately later, to estimate the difference between COCTS detectors and remove the striped noise.

\subsection{Filtering of Matchups}

Because the spatial resolution of IASI is much larger than COCTS, the homogeneity of each IASI IFOV is very important. Radiance nonuniformity within the IASI IFOV increases the spatial uncertainties of matchups because of the different point spread functions between IASI and COCTS as well as increasing the error due to geolocation errors $[15,16]$. We used the relative standard deviation, which is the standard deviation/mean of the COCTS valid pixels inside each IASI IFOV, to quantify the homogeneity. We also used a perimeter region outside the central collocation area to reduce the likelihood of time variable components such as errors caused by differences in the cloud and/or clear distributions in a similar way to that suggested by GSICS [21]. For the COCTS and IASI gridded radiance after equal-angle projection, we calculated the relative standard deviation of COCTS pixels at $0.12^{\circ} \times 0.12^{\circ}$ region (shown as the yellow region of Figure 2 ) to estimate the uniformity of the corresponding IASI IFOV, and the relative standard deviation of surrounding pixels around the target region within $0.16^{\circ}$ (shown as the green region) as the estimation of homogeneity in the wider surroundings. Figure 3 shows the variations of COCTS 11 and $12 \mu \mathrm{m}$ channel radiance minus IASI radiance difference against the relative standard deviation of COCTS pixels in target region (Figure $3 a, c$ ) and surrounding environment region (Figure 3b,d), respectively. The plotted colour indicates the number of collocations in every 0.0005 relative standard deviation bin and in $0.15 \mathrm{~mW} \mathrm{~m}^{-2} \mathrm{~cm} \mathrm{sr}^{-1}$ radiance difference bin. The radiance differences in both target region and surrounding environment region become larger with the larger relative standard deviations, indicating that the relative standard deviation is an effective factor to control the matchup spatial uncertainties. According to the distribution pattern for different channels and different regions, we chose different thresholds (shown as black vertical lines in Figure 3) to select matchups located in uniform scenes. For $11 \mu \mathrm{m}$ channel, we chose the matchups with the COCTS relative standard deviation in the target and surrounding region smaller than 0.006 and 0.01 , respectively. For $12 \mu \mathrm{m}$ channel, we chose the matchups with the COCTS relative standard deviations in target and surrounding region smaller than 0.01 and 0.013 , respectively. Both criteria on relative standard deviation must be met for both channels for the matchup to be retained. The total number of filtered matchups of COCTS and IASI in uniform scenes from 2009 to 2011 is 11,250 and all of the subsequent analysis and correction are based on these filtered matchups. 


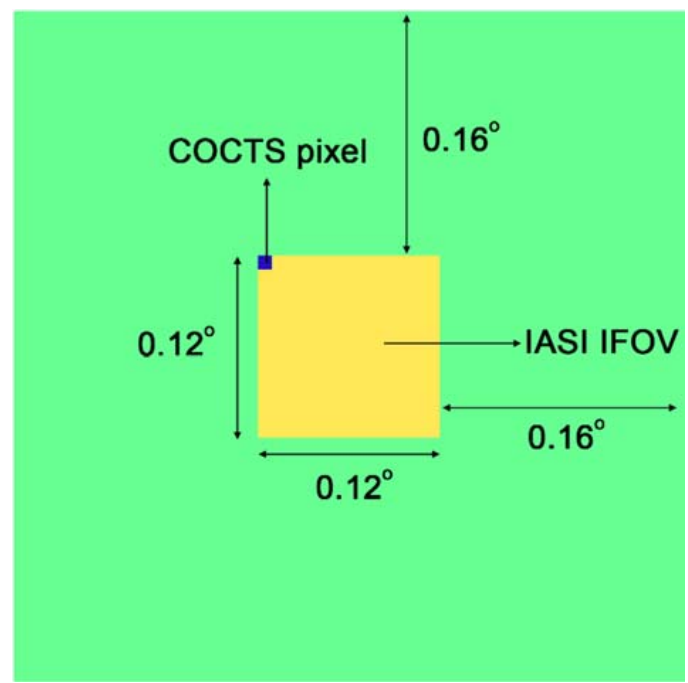

Figure 2. Illustration of the homogeneity estimation region. The smallest blue square represents one gridded COCTS pixel with the spatial resolution of $0.01^{\circ}$. The yellow square represents the COCTS pixels assumed to correspond to one IASI IFOV with spatial resolution of $0.12^{\circ}$. (Use of a square in the COCTS is an approximation that is only good if the area is adequately homogeneous.) The green region represents the surrounding area within $0.16^{\circ}$.

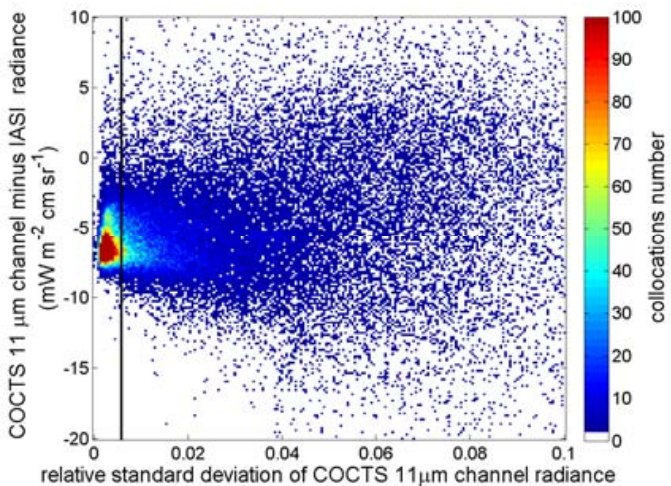

(a)

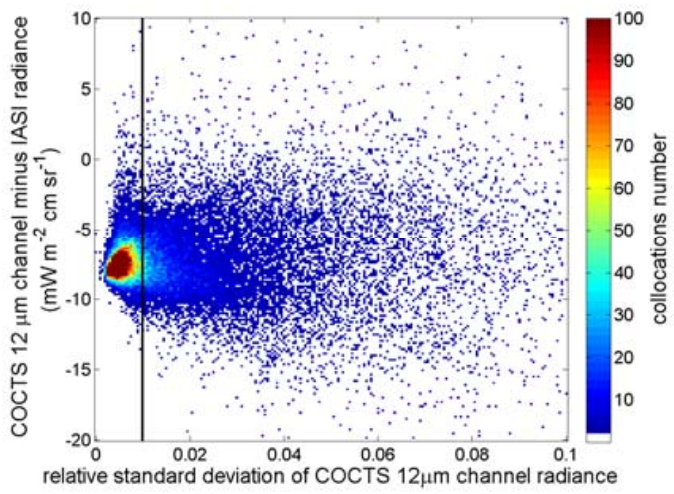

(c)

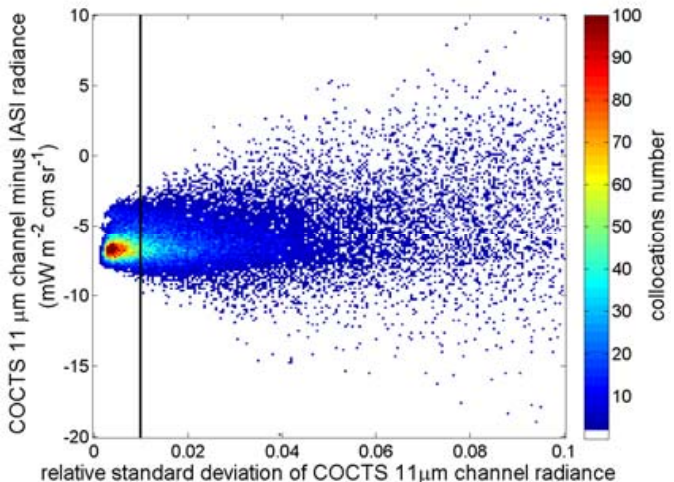

(b)

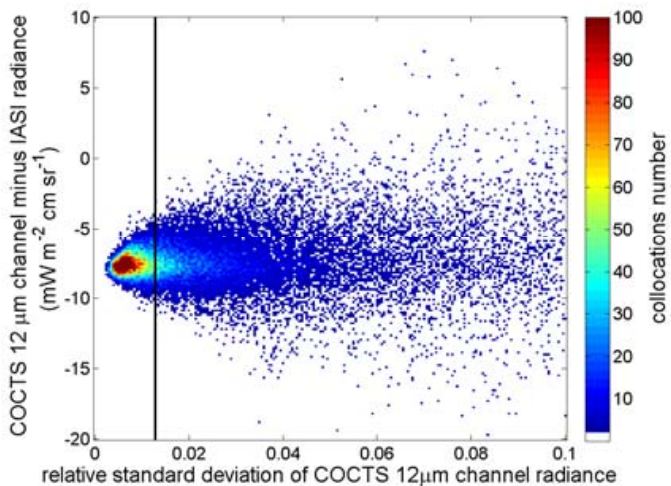

(d)

Figure 3. The variations of COCTS 11 and $12 \mu \mathrm{m}$ channel radiance minus IASI radiance difference against relative standard deviations of COCTS radiance in target regions and surrounding regions: (a) $11 \mu \mathrm{m}$ channel in target region; (b) $11 \mu \mathrm{m}$ channel in surrounding region; (c) $12 \mu \mathrm{m}$ channel in target region; and (d) $12 \mu \mathrm{m}$ channel in surrounding region. 


\section{Comparison of COCTS Radiance with IASI}

Based on these 11,250 filtered matchups presented in Section 2, COCTS radiance from 11 and $12 \mu \mathrm{m}$ channel are compared with IASI. Figure $4 \mathrm{a}$,c shows the scatter plots of COCTS 11 and $12 \mu \mathrm{m}$ channel radiance with IASI radiance, respectively. The background colour indicates the collocation numbers in every $0.2 \mathrm{~mW} \mathrm{~m}^{-2} \mathrm{~cm} \mathrm{sr}^{-1}$ COCTS and IASI radiance bin. The overall statistics of COCTS with IASI radiance indicate large cold biases of $-6.35 \mathrm{~mW} \mathrm{~m}^{-2} \mathrm{~cm} \mathrm{sr}^{-1}$ and $-7.56 \mathrm{~mW} \mathrm{~m}^{-2} \mathrm{~cm} \mathrm{sr}^{-1}$, with the corresponding standard deviations of $0.96 \mathrm{~mW} \mathrm{~m}^{-2} \mathrm{~cm} \mathrm{sr}^{-1}$ and $0.63 \mathrm{~mW} \mathrm{~m}^{-2} \mathrm{~cm} \mathrm{sr}^{-1}$. Figure $4 \mathrm{~b}$,d indicates the variations of COCTS 11 and $12 \mu \mathrm{m}$ channel radiance minus IASI radiance against IASI radiance, respectively. Again, the background colour indicates the number of collocations in every $0.2 \mathrm{~mW} \mathrm{~m}^{-2} \mathrm{~cm} \mathrm{sr}^{-1}$ IASI radiance bin and in $0.02 \mathrm{~mW} \mathrm{~m}^{-2} \mathrm{~cm} \mathrm{sr}^{-1}$ radiance difference bin. The purple solid line shows mean values of the radiance difference in IASI radiance bins of width $2 \mathrm{~mW} \mathrm{~m}^{-2} \mathrm{~cm} \mathrm{sr}^{-1}$, with the corresponding black vertical bars indicating two times the uncertainty in the mean (i.e., the standard deviation $/ \sqrt{n}$ ). For COCTS 11 and $12 \mu \mathrm{m}$ channel, both radiance differences represent approximately linear dependence on radiance. The difference for COCTS $11 \mu \mathrm{m}$ channel more obviously depends on scene radiance than for $12 \mu \mathrm{m}$ channel. For $11 \mu \mathrm{m}$ channel, the mean value of radiance difference is about $-3.3 \mathrm{~mW} \mathrm{~m} \mathrm{~m} \mathrm{sr}^{-1}$ when radiance is around $70 \mathrm{~mW} \mathrm{~m}^{-2} \mathrm{~cm} \mathrm{sr}^{-1}$, becoming around $-7.4 \mathrm{~mW} \mathrm{~m}^{-2} \mathrm{~cm} \mathrm{sr}^{-1}$ when the IASI radiance is about $110 \mathrm{~mW} \mathrm{~m}^{-2} \mathrm{~cm} \mathrm{sr}^{-1}$. The radiance difference of $12 \mu \mathrm{m}$ channel has a less-strong dependence on IASI radiance, spanning roughly $-7 \mathrm{~mW} \mathrm{~m}^{-2} \mathrm{~cm} \mathrm{sr}^{-1}$ to $-8 \mathrm{~mW} \mathrm{~m}^{-2} \mathrm{~cm} \mathrm{sr}^{-1}$ over the matchup range.

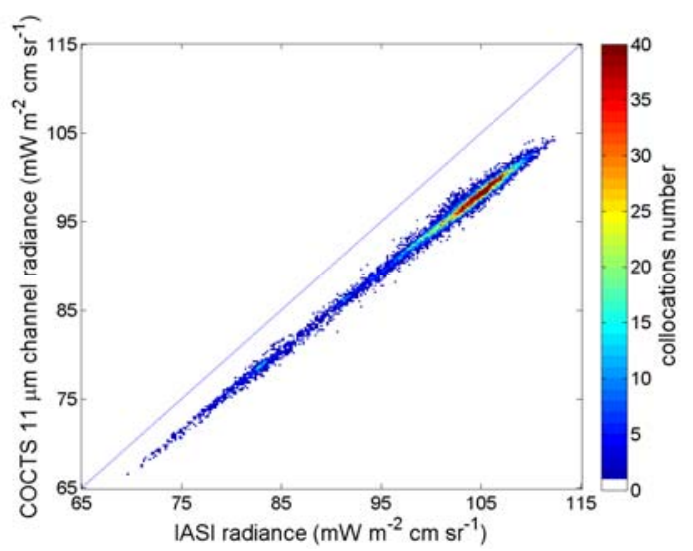

(a)

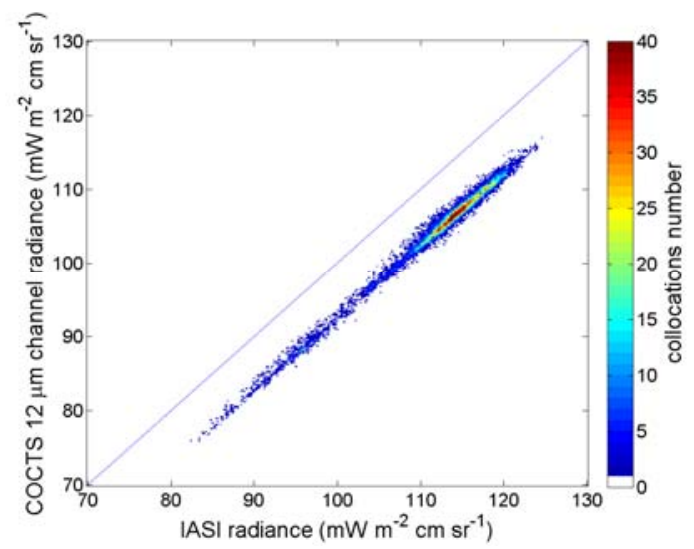

(c)

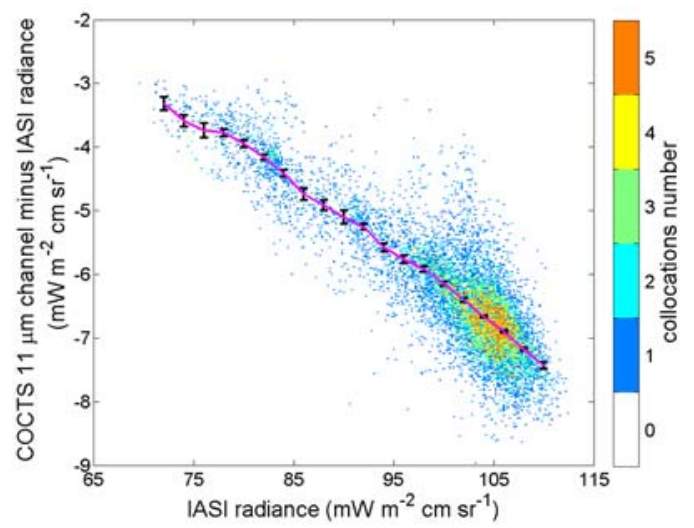

(b)

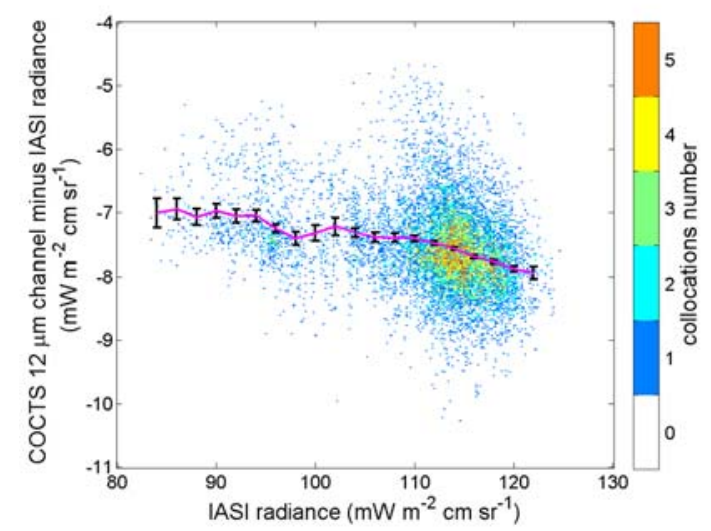

(d)

Figure 4. The scatter plots of COCTS: (a) $11 \mu \mathrm{m}$ channel; and (c) $12 \mu \mathrm{m}$ channel original radiance with IASI; and the variations of COCTS: (b) $11 \mu \mathrm{m}$ channel; and (d) $12 \mu \mathrm{m}$ channel original radiance minus IASI radiance difference against IASI radiance. 
There is distinct striped noise with a pattern approximately repeating every four scan lines in COCTS radiance image, due to the inconsistency between four parallel detectors [4]. Similar striping is also seen on other whiskbroom scanning radiometers, such as the Moderate Resolution Imaging Spectroradiometer (MODIS) and Visible Infrared Imaging Radiometer Suite (VIIRS) [22-25]. To estimate the measurement difference between different detectors, the COCTS pixels inside each IASI IFOV measured by individual detectors are averaged separately. Then, the COCTS radiance from four detectors (called Detector 1, Detector 2, Detector 3, and Detector 4 hereafter) are compared with IASI separately. Figure 5 represents the comparisons of COCTS radiance measured by four individual detectors with IASI radiance. Similar to the purple solid lines shown in Figure $4 b$,d, the solid lines in difference colours of Figure 5 are the variations of mean difference in IASI radiance bins of width $2 \mathrm{~mW} \mathrm{~m}^{-2} \mathrm{~cm} \mathrm{sr}^{-1}$, with the corresponding two times the uncertainty in the mean shown as the vertical bars in the same colour. Table 1 indicates the overall statistics of COCTS minus IASI radiance difference, including the comparison results of all detector measurements as well as measurements from four individual detectors. For $11 \mu \mathrm{m}$ channel, the comparison results show smaller difference between adjacent detectors with the maximum difference of $0.22 \mathrm{~mW} \mathrm{~m}^{-2} \mathrm{~cm} \mathrm{sr}^{-1}$ corresponding to Detector 3 and Detector 4. In addition, when the radiances larger than $95 \mathrm{~mW} \mathrm{~m}^{-2} \mathrm{~cm} \mathrm{sr}^{-1}$, the difference among Detector 1, Detector 2 and Detector 4 are very minor. However, for $12 \mu \mathrm{m}$ channel, both the variation plots and the statistics results indicate the difference between adjacent detectors are larger than $11 \mu \mathrm{m}$ channel in the whole radiance range, which is consistent with more obvious striped noise shown in COCTS $12 \mu \mathrm{m}$ channel radiance image.

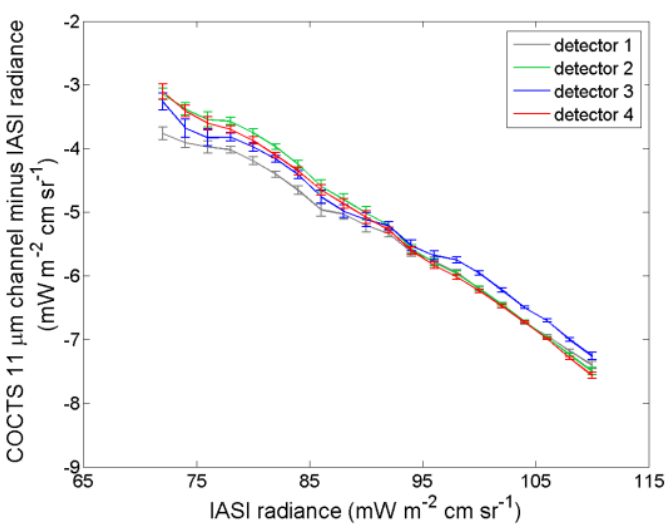

(a)

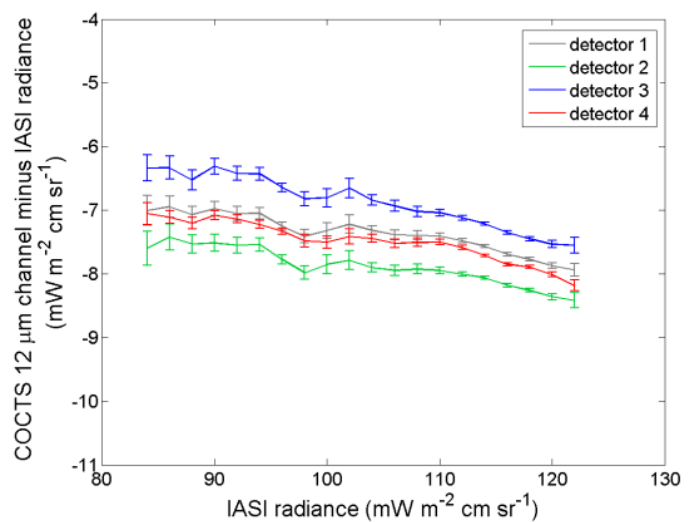

(b)

Figure 5. The variations of COCTS (a) $11 \mu \mathrm{m}$ channel and (b) $12 \mu \mathrm{m}$ channel radiance measured by four detectors (grey line: Detector 1; green line: Detector 2; blue line: Detector 3; and red line: Detector 4) minus IASI radiance difference against IASI radiance.

Table 1. The statistics of COCTS minus IASI radiance difference from 2009 to 2011.

\begin{tabular}{|c|c|c|c|c|c|}
\hline & $\begin{array}{c}\text { COCTS } \\
\text { All Detectors }\end{array}$ & $\begin{array}{l}\text { COCTS } \\
\text { Detector } 1\end{array}$ & $\begin{array}{l}\text { COCTS } \\
\text { Detector } 2\end{array}$ & $\begin{array}{l}\text { COCTS } \\
\text { Detector } 3\end{array}$ & $\begin{array}{l}\text { COCTS } \\
\text { Detector } 4\end{array}$ \\
\hline & Mean/Std.Dev & Mean/Std.Dev & Mean/Std.Dev & Mean/Std.Dev & Mean/Std.Dev \\
\hline $\begin{array}{c}11 \mu \mathrm{m} \text { channel radiance } \\
\text { difference }\left(\mathrm{mW} \mathrm{m} \mathrm{m}^{-2} \mathrm{~cm} \mathrm{sr}^{-1}\right)\end{array}$ & $-6.35 / 0.96$ & $-6.42 / 0.93$ & $-6.38 / 1.02$ & $-6.20 / 0.94$ & $-6.42 / 0.99$ \\
\hline $\begin{array}{c}12 \mu \mathrm{m} \text { channel radiance } \\
\text { difference }\left(\mathrm{mW} \mathrm{m} \mathrm{m}^{-2} \mathrm{~cm} \mathrm{sr}^{-1}\right)\end{array}$ & $-7.56 / 0.63$ & $-7.30 / 0.69$ & $-8.06 / 0.66$ & $-7.18 / 0.72$ & $-7.69 / 0.57$ \\
\hline
\end{tabular}

Figure 6 is the time series plot of COCTS minus IASI radiance difference from 2009 to 2011 (Figure $6 \mathrm{a}$ for COCTS $11 \mu \mathrm{m}$ channel and Figure $6 \mathrm{~b}$ for COCTS $12 \mu \mathrm{m}$ channel). The lower blue points in each figure indicate the daily mean values of the COCTS minus IASI radiance difference and the 
red vertical bars are the daily uncertainties in the means, corresponding to the left y-axis. The upper black points represent the daily averaged IASI radiances corresponding to the right y-axis. There are some missing values when there are no matchups or the COCTS data are invalid during these days. Figure 6a represents a strong negative correlation between $11 \mu \mathrm{m}$ channel radiance difference and IASI radiance that is consistent with overall three-year comparison results, also leading to strong fluctuations of daily biases. In other words, the fluctuation of biases from $11 \mu \mathrm{m}$ channel is dominated by a radiance-dependent variation, not by a time-dependent variation. For $12 \mu \mathrm{m}$ channel, there is no obvious daily radiance difference dependence on IASI radiance shown, and the biases keep relatively stable, except for a difference jump about $1 \mathrm{~mW} \mathrm{~m}^{-2} \mathrm{~cm} \mathrm{sr}^{-1}$ decreasing at the junction point between March and April 2011 (shown as the black circle of the lower line in Figure 6b). Thus, the overall calibration of COCTS thermal infrared channels was stable from 2009 to 2011, except for the calibration drifting at the beginning of April 2011.

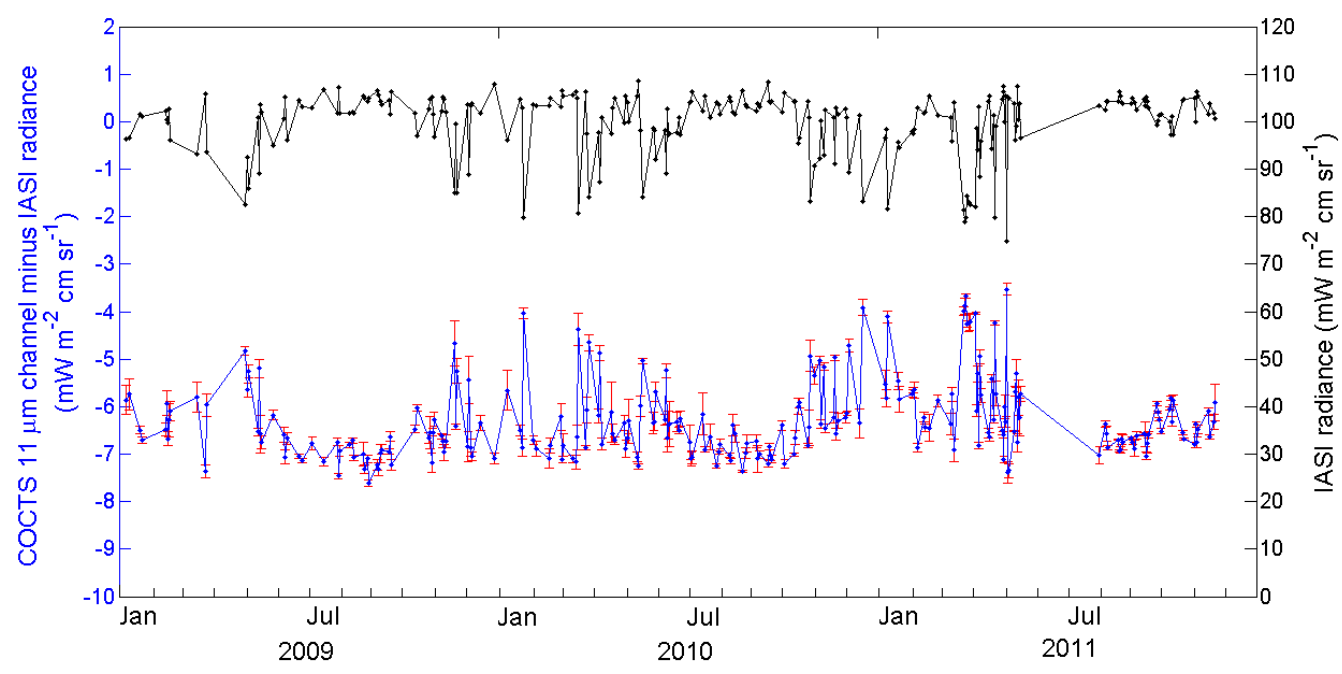

(a)

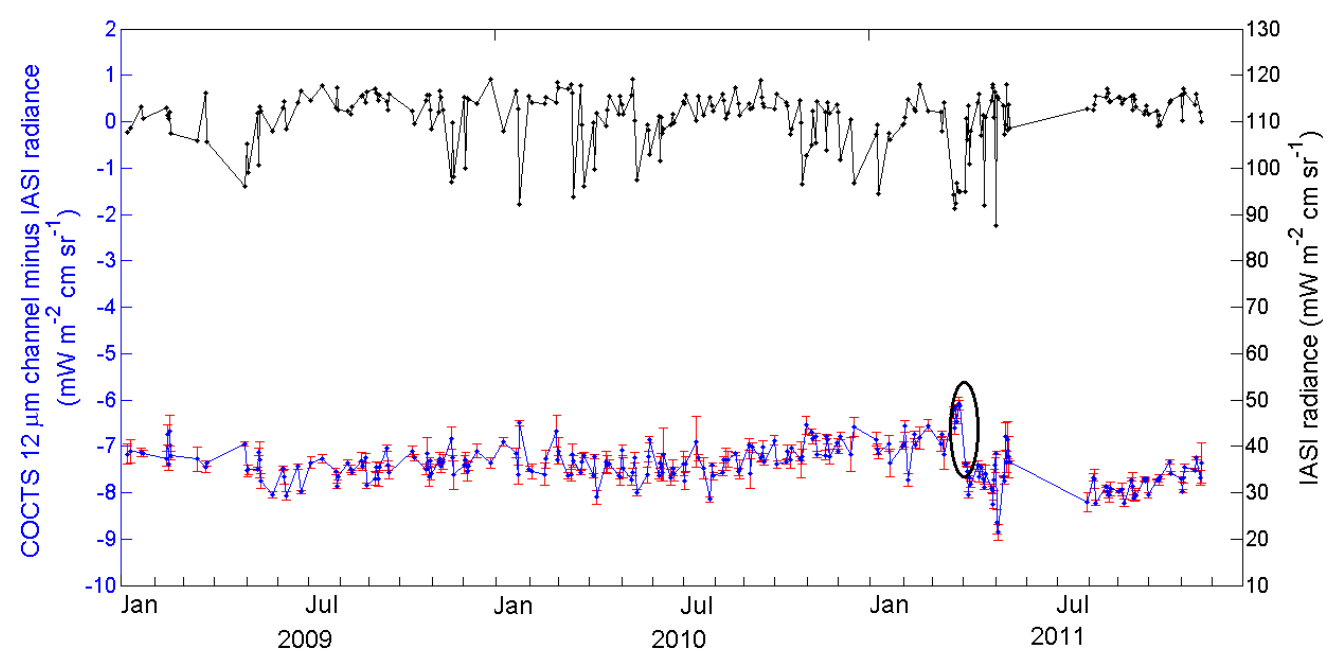

(b)

Figure 6. The time series plot of COCTS original radiance minus IASI radiance difference from 2009 to 2011: (a) COCTS $11 \mu \mathrm{m}$ channel; and (b) COCTS $12 \mu \mathrm{m}$ channel. 


\section{Calculation of Coefficients for COCTS Radiance Correction}

The coefficients of COCTS radiance correction are obtained based on the filtered matchups of COCTS with IASI radiance. We use the robust linear regression to obtain the slope, $a$, and offset, $b$, of the relationship between COCTS minus IASI radiance difference and IASI radiance, represented as the Equation (2):

$$
\begin{gathered}
L_{\text {COCTS }}-L_{\text {IASI }}=a \times L_{\text {IASI }}+b \\
L_{\text {COCTSI }}=\frac{L_{\text {COCTS }}-b}{a+1}
\end{gathered}
$$

where the $L_{\text {COCTS }}$ and $L_{\text {IASI }}$ represent the COCTS and IASI original radiances, respectively. The COCTS original radiances are fitted to IASI data using Equation (2), therefore the COCTS corrected radiance $L_{\text {COCTSI }}$ (substituting $L_{C O C T S \text { I }}$ for $L_{I A S I}$ ) are given using Equation (3). A randomly selected subset, $2 / 3$ of the whole matchup dataset, was used for regression and the remaining $1 / 3$ were used for validation. Due to the calibration drifting at the junction point between March and April 2011, two periods during 2009 to 2011 are analysed separately. Period 1 is from January 2009 to March 2011 and Period 2 is from April 2011 to December 2011. Coefficients for COCTS radiance corrections were calculated separately in Period 1 and Period 2. In addition, considering the different comparison results for COCTS four detectors shown in Section 3, the regression coefficients for different COCTS detectors were obtained separately. Table 2 shows the coefficients for COCTS 11 and $12 \mu \mathrm{m}$ channel radiance correction of different detectors in two periods separately. Then, the COCTS radiances measured by each detector were corrected using individual coefficients to reduce the striped noise due to nonuniformity of individual detectors.

\begin{tabular}{|c|c|c|c|c|c|c|c|c|}
\hline \multirow[b]{3}{*}{$\begin{array}{c}11-\mu \mathrm{m} \\
\text { channel }\end{array}$} & \multicolumn{4}{|c|}{ Period 1 (January 2009-March 2011) } & \multicolumn{4}{|c|}{ Period 2 (April 2011-December 2011) } \\
\hline & $\begin{array}{c}\text { Detector } 1 \\
(a / b)\end{array}$ & $\begin{array}{c}\text { Detector } 2 \\
(a / b)\end{array}$ & $\begin{array}{c}\text { Detector } 3 \\
(a / b)\end{array}$ & $\begin{array}{c}\text { Detector } 4 \\
(a / b)\end{array}$ & $\begin{array}{c}\text { Detector } 1 \\
(a / b)\end{array}$ & $\begin{array}{c}\text { Detector } 2 \\
(a / b)\end{array}$ & $\begin{array}{c}\text { Detector } 3 \\
(a / b)\end{array}$ & $\begin{array}{c}\text { Detector } 4 \\
(a / b)\end{array}$ \\
\hline & $-0.11 / 4.30$ & $-0.12 / 5.88$ & $-0.11 / 4.79$ & $-0.12 / 5.69$ & $-0.11 / 4.42$ & $-0.12 / 6.15$ & $-0.10 / 4.33$ & $-0.12 / 5.76$ \\
\hline $\begin{array}{l}12-\mu m \\
\text { channel }\end{array}$ & $-0.02 /-4.47$ & $-0.03 /-4.69$ & $-0.03 /-2.98$ & $-0.03 /-4.41$ & $-0.01 /-6.51$ & $-0.02 /-6.10$ & $-0.04 /-3.29$ & $-0.03 /-4.50$ \\
\hline
\end{tabular}

Table 2. The coefficients for COCTS radiance correction.

\section{Validation of COCTS Corrected Radiance}

The comparison results of COCTS 11 and $12 \mu \mathrm{m}$ channel corrected radiance with IASI are shown as Figure 7. Figure $7 \mathrm{a}, \mathrm{c}$ shows scatter plots, while Figure $7 \mathrm{~b}, \mathrm{~d}$ presents the variations of radiance difference against IASI radiance after correction. Table 3 is the statistics of comparison results before and after correction based on the validation matchups. In Table 3, the mean differences and standard deviations of COCTS 11 and $12 \mu \mathrm{m}$ channel radiance with IASI in two periods separately and combined are provided. The large biases between COCTS original radiance and IASI radiance are removed after correction, with the value of $-0.02 \mathrm{~mW} \mathrm{~m}^{-2} \mathrm{~cm} \mathrm{sr}^{-1}$ and $-0.01 \mathrm{~mW} \mathrm{~m}^{-2} \mathrm{~cm} \mathrm{sr}^{-1}$ for 11 and $12 \mu \mathrm{m}$ channel during the whole period from January 2009 to December 2011, respectively. For $11 \mu \mathrm{m}$ channel, the significant radiance-dependent pattern of radiance difference is corrected, with the reduced overall standard deviation from $0.95 \mathrm{~mW} \mathrm{~m}{ }^{-2} \mathrm{~cm} \mathrm{sr}^{-1}$ to $0.51 \mathrm{~mW} \mathrm{~m} \mathrm{~cm} \mathrm{sr}^{-1}$. A reduction in the bias and standard deviation between the COCTS and IASI is also seen for $12 \mu \mathrm{m}$ channel. We have also provided the same statistics in brightness temperature (BT) space for ease of comprehension. As shown in Table 3, the overall mean differences of COCTS 11 and $12 \mu \mathrm{m}$ channel original BTs with IASI are $-4.08 \mathrm{~K}$ and $-4.76 \mathrm{~K}$, with the corresponding standard deviations of $0.50 \mathrm{~K}$ and $0.39 \mathrm{~K}$. After correction, both mean values of COCTS 11 and $12 \mu \mathrm{m}$ channel corrected BTs minus IASI are $-0.01 \mathrm{~K}$, with the corresponding standard deviations of $0.33 \mathrm{~K}$ and $0.35 \mathrm{~K}$ respectively. 


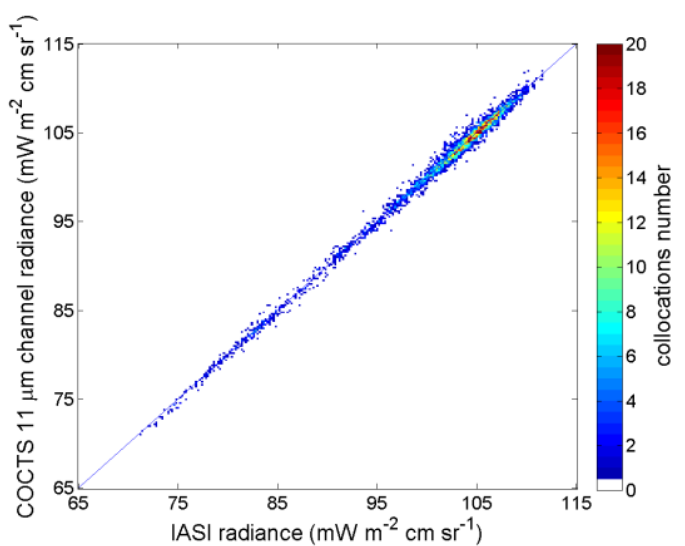

(a)

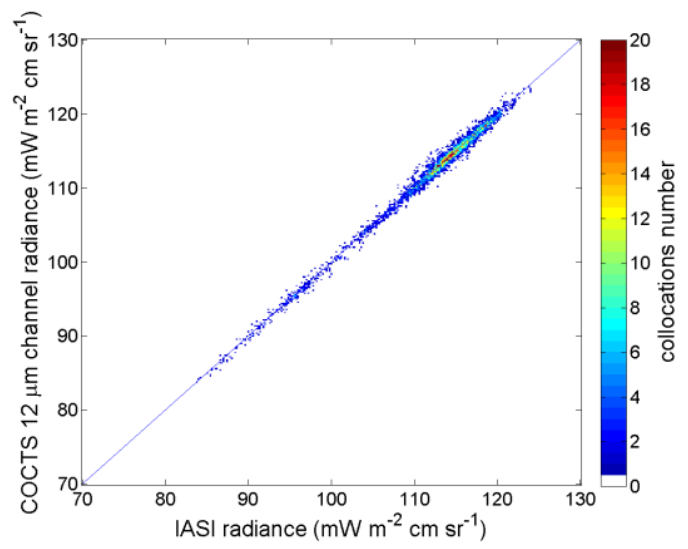

(c)

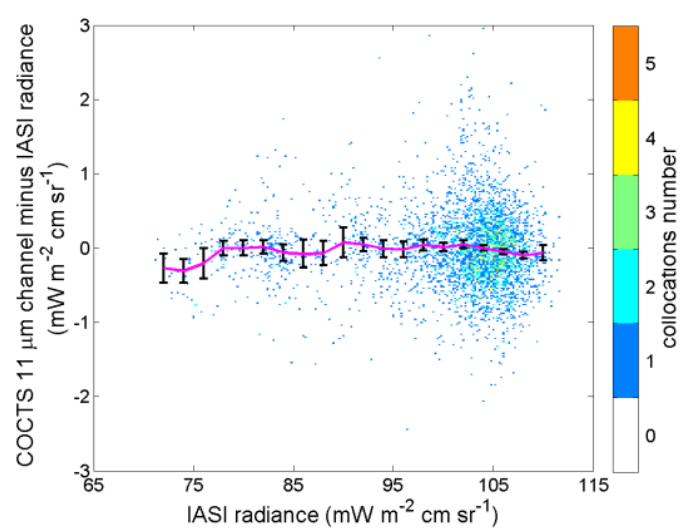

(b)

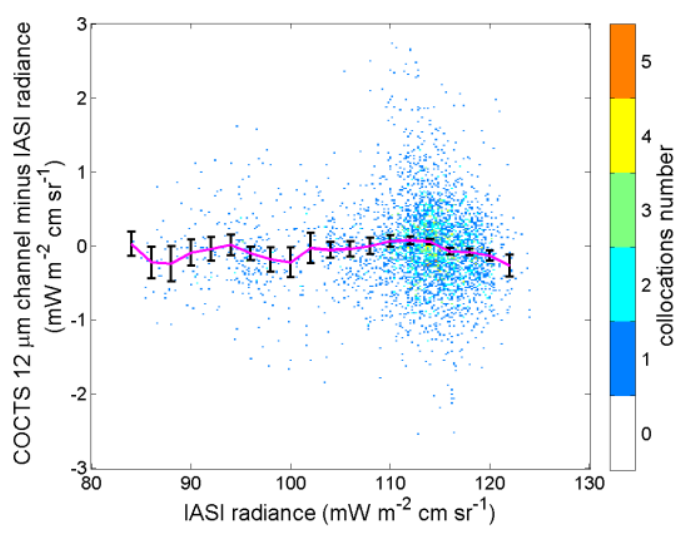

(d)

Figure 7. The scatter plots of COCTS: (a) $11 \mu \mathrm{m}$ channel; and (c) $12 \mu \mathrm{m}$ channel corrected radiance with IASI; and the variations of COCTS: (b) $11 \mu \mathrm{m}$ channel; and (d) $12 \mu \mathrm{m}$ channel corrected radiance minus IASI radiance difference against IASI radiance.

Table 3. The statistics of radiance and BT difference between COCTS and IASI before and after correction.

\begin{tabular}{|c|c|c|c|c|c|}
\hline & & $\begin{array}{c}11 \mu \mathrm{m} \text { Channel } \\
\text { Radiance Difference } \\
\left(\mathrm{mW} \mathrm{m} \mathrm{m} \mathrm{sm}^{-1}\right)\end{array}$ & $\begin{array}{c}11 \mu \mathrm{m} \\
\text { Channel BT } \\
\text { Difference K) }\end{array}$ & $\begin{array}{c}12 \mu \mathrm{m} \text { Channel } \\
\text { Radiance Difference } \\
\left(\mathrm{mW} \mathrm{m} \mathrm{m} \mathrm{sr}^{-1}\right)\end{array}$ & $\begin{array}{c}12 \mu \mathrm{m} \\
\text { Channel BT } \\
\text { Difference (K) }\end{array}$ \\
\hline & & Mean/Std.Dev & Mean/Std.Dev & Mean/Std.Dev & Mean/Std.Dev \\
\hline $\begin{array}{l}\text { Period } 1 \text { (January 2009- } \\
\text { March 2011) }\end{array}$ & $\begin{array}{l}\text { Before correction } \\
\text { After correction }\end{array}$ & $\begin{array}{c}-6.45 / 1.05 \\
0.01 / 0.56\end{array}$ & $\begin{array}{c}-4.15 / 0.55 \\
0.00 / 0.36\end{array}$ & $\begin{array}{c}-7.27 / 0.64 \\
0.00 / 0.63\end{array}$ & $\begin{array}{c}-4.58 / 0.40 \\
0.00 / 0.39\end{array}$ \\
\hline $\begin{array}{l}\text { Period } 2 \text { (April 2011- } \\
\text { December 2011) }\end{array}$ & $\begin{array}{l}\text { Before correction } \\
\text { After correction }\end{array}$ & $\begin{array}{l}-6.31 / 0.88 \\
-0.03 / 0.47\end{array}$ & $\begin{array}{l}-4.04 / 0.46 \\
-0.02 / 0.30\end{array}$ & $\begin{array}{l}-7.75 / 0.54 \\
-0.03 / 0.53\end{array}$ & $\begin{array}{l}-4.87 / 0.34 \\
-0.02 / 0.32\end{array}$ \\
\hline $\begin{array}{l}\text { All (January 2009- } \\
\text { December 2011) }\end{array}$ & $\begin{array}{l}\text { Before correction } \\
\text { After correction }\end{array}$ & $\begin{array}{l}-6.37 / 0.95 \\
-0.02 / 0.51\end{array}$ & $\begin{array}{l}-4.08 / 0.50 \\
-0.01 / 0.33\end{array}$ & $\begin{array}{l}-7.57 / 0.62 \\
-0.01 / 0.57\end{array}$ & $\begin{array}{l}-4.76 / 0.39 \\
-0.01 / 0.35\end{array}$ \\
\hline
\end{tabular}

The time series plots of COCTS 11 and $12 \mu \mathrm{m}$ channel corrected radiance minus IASI are shown in Figure 8a,b respectively. Similar to Figure 6, the upper black lines are daily mean values of IASI radiance, and the lower blue lines are the daily variations of COCTS corrected radiance minus IASI difference with the corresponding uncertainties shown as red vertical lines. For $11 \mu \mathrm{m}$ channel, compared with Figure 6a, the fluctuations of radiance difference become much smoother. In addition, the jump of $12 \mu \mathrm{m}$ channel radiance difference at the junction point between March and April 2011 is 
not represented again in Figure 8b, indicating that the different coefficients applied in two periods separately is reasonable to correct COCTS calibration drifting.

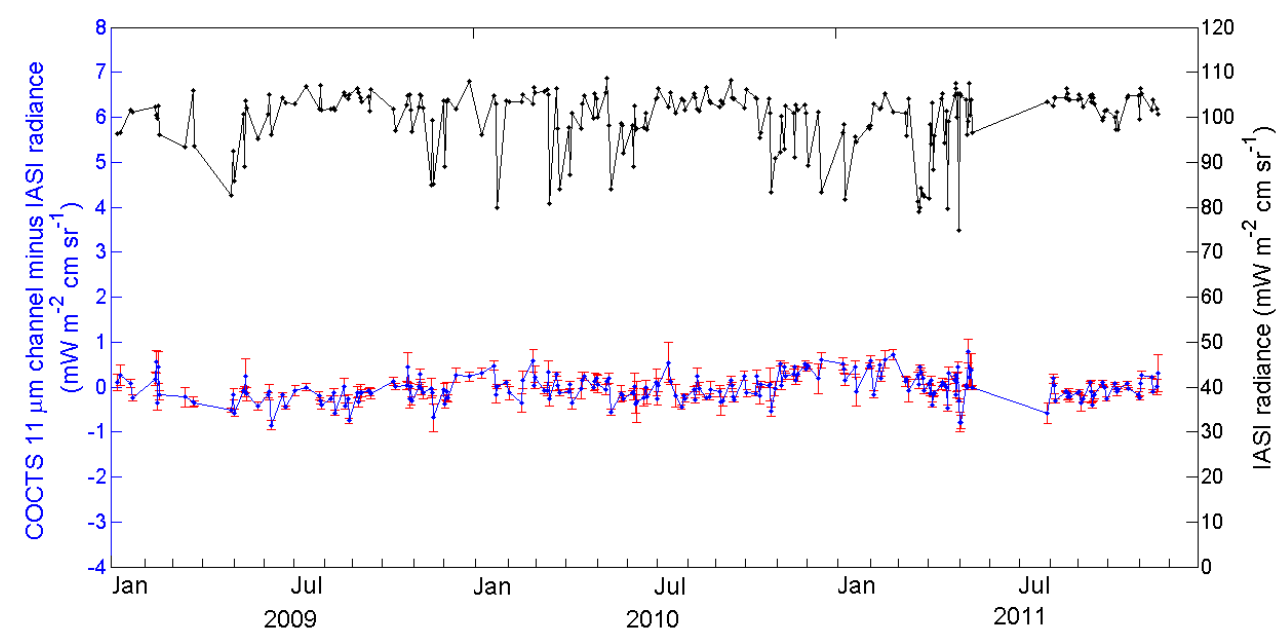

(a)

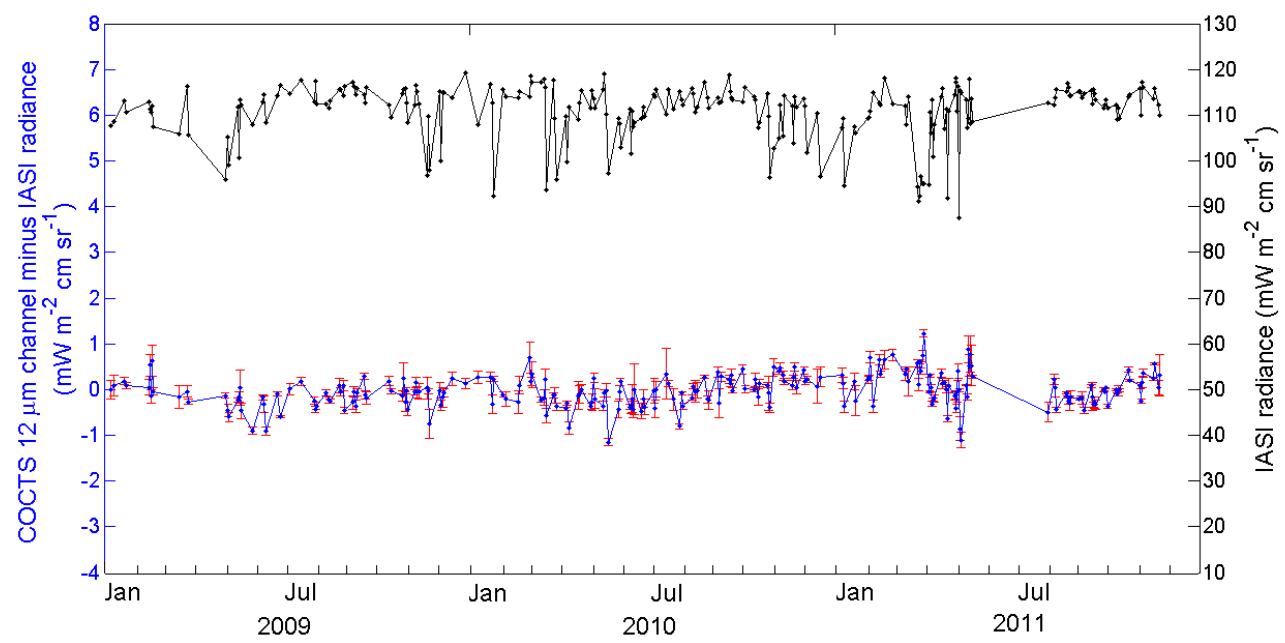

(b)

Figure 8. The time series plot of COCTS corrected radiance minus IASI radiance difference from 2009 to 2011: (a) COCTS $11 \mu \mathrm{m}$ channel; and (b) COCTS $12 \mu \mathrm{m}$ channel.

\section{Post-Recalibration Improvement in Striped Noise Reduction}

Figures 9 and 10 are regional radiance images of COCTS 11 and $12 \mu \mathrm{m}$ channel on 12 May 2011, respectively, with Figures 9a and 10a being the original data and Figures $9 \mathrm{~b}$ and $10 \mathrm{~b}$ the corrected data. The blue plots indicate radiance variations along track at the location of black lines painted in each radiance image. The radiance images, as well as the significant fluctuations of original radiance variations, display the strong striping in COCTS radiance data. In addition, the larger difference between neighbour detectors of $12 \mu \mathrm{m}$ channel indicates that the striping of $12 \mu \mathrm{m}$ channel radiance is stronger than $11 \mu \mathrm{m}$ channel. After the correction of COCTS original radiance using individual coefficients for four detector measurements, the striped noise shown in corrected COCTS radiance images is reduced, with smoother variations along track, demonstrating that the inter-calibration method in this study is useful in some extent for COCTS striped noise elimination. Moreover, 
the histogram statistics of local standard deviations over 3 by 3 pixels box $\left(\mathrm{LSD}_{3 \times 3}\right)$ of the whole scene radiance is applied to evaluate the noise level quantitatively. Figure $11 \mathrm{a}$,b shows the $\mathrm{LSD}_{3 \times 3}$ histogram curves of original radiance (red curve) and corrected radiance (blue curve) from COCTS 11 and $12 \mu \mathrm{m}$ channels on 12 May 2011, respectively. The $\operatorname{LSD}_{3 \times 3}$ value corresponding to the peak number reflects the noise level. For $11 \mu \mathrm{m}$ channel original radiance and corrected radiance, the $\mathrm{LSD}_{3 \times 3}$ peak values are $0.18 \mathrm{~mW} \mathrm{~m}^{-2} \mathrm{~cm} \mathrm{sr}^{-1}$ and $0.13 \mathrm{~mW} \mathrm{~m}^{-2} \mathrm{~cm} \mathrm{sr}^{-1}$ respectively. For $12 \mu \mathrm{m}$ channel, after correction, the $\mathrm{LSD}_{3 \times 3}$ peak value decrease from $0.41 \mathrm{~mW} \mathrm{~m}^{-2} \mathrm{~cm} \mathrm{sr}^{-1}$ to $0.11 \mathrm{~mW} \mathrm{~m}^{-2} \mathrm{~cm} \mathrm{sr}^{-1}$. The histogram patterns and $\mathrm{LSD}_{3 \times 3}$ peak values indicate the noise COCTS $12 \mu \mathrm{m}$ channel in the original data is stronger than $11 \mu \mathrm{m}$ channel, which is consistent with the striped noise analysis results. After inter-calibration, the noise levels in both channels are decreased, and the improvement of $12 \mu \mathrm{m}$ channel is greater than $11 \mu \mathrm{m}$ channel, mainly due to the distinguishable difference between neighbour detectors of $12 \mu \mathrm{m}$ channel. The radiance inter-calibration does not fully eliminate apparent striping, presumably because of residual error or temporal evolution of the calibration differing between detectors. Nonetheless, the improvements of COCTS radiance accuracy after inter-calibration are essential for improved SST retrieval from COCTS, which will be the topic of future work.

\section{COCTS $11 \mu \mathrm{m}$ channel original radiance}
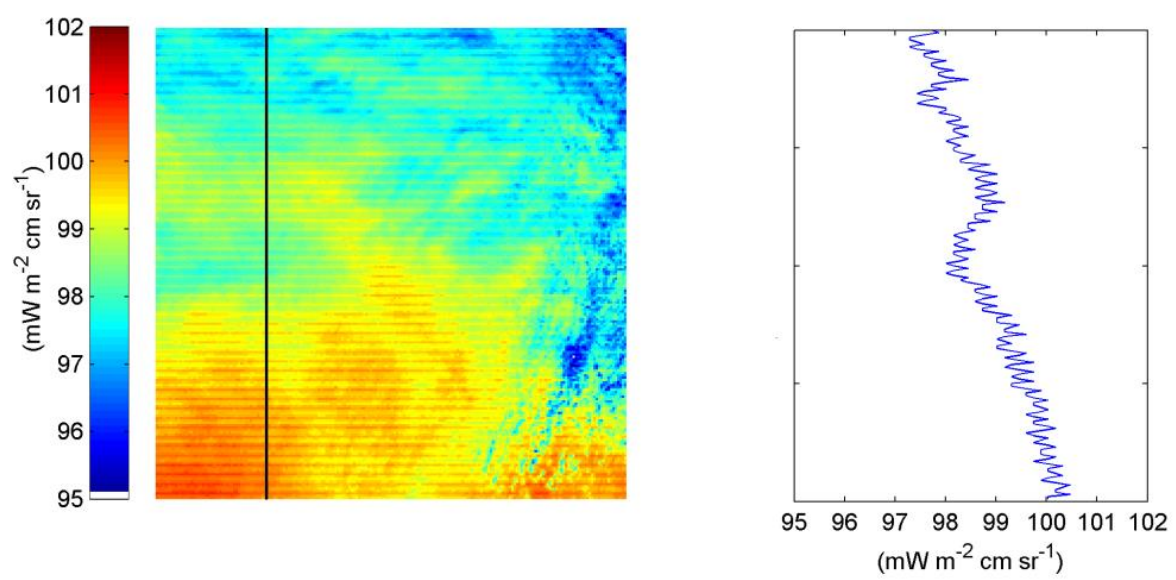

(a)

COCTS $11 \mu \mathrm{m}$ channel corrected radiance
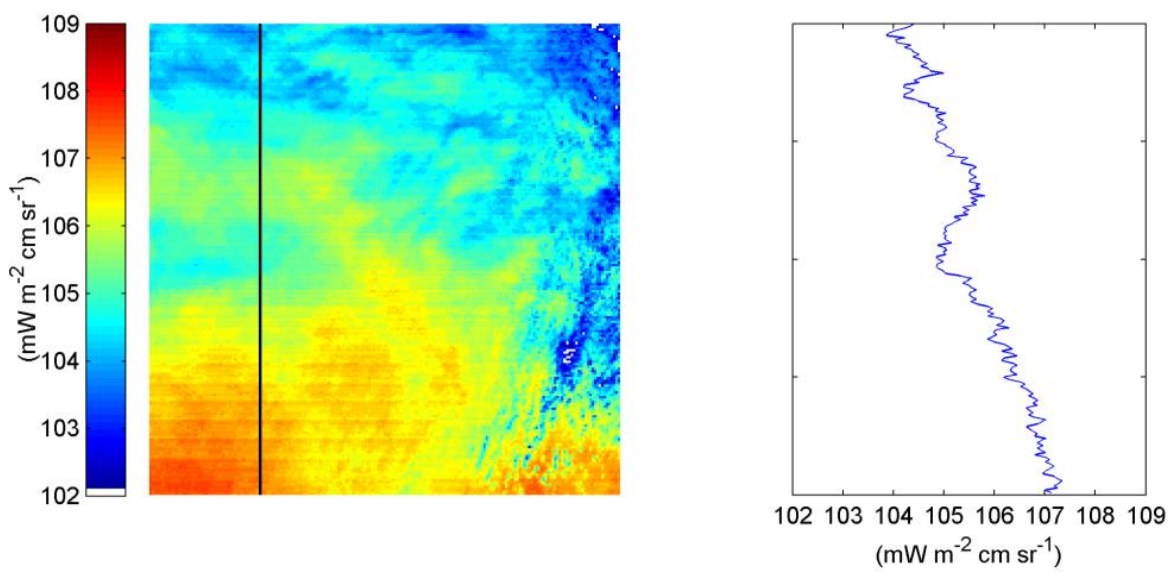

(b)

Figure 9. COCTS $11 \mu \mathrm{m}$ channel original and corrected regional radiance of $200 \times 200$ pixels size on 12 May 2011: (a) original radiance; and (b) corrected radiance. The blue plots in right panels indicate COCTS $11 \mu \mathrm{m}$ channel radiance variations along track at the location of black lines painted in left panels. 
COCTS $12 \mu \mathrm{m}$ channel original radiance

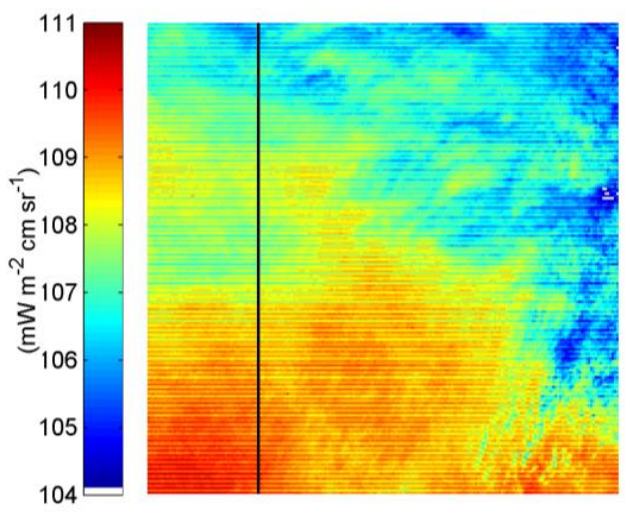

(a)

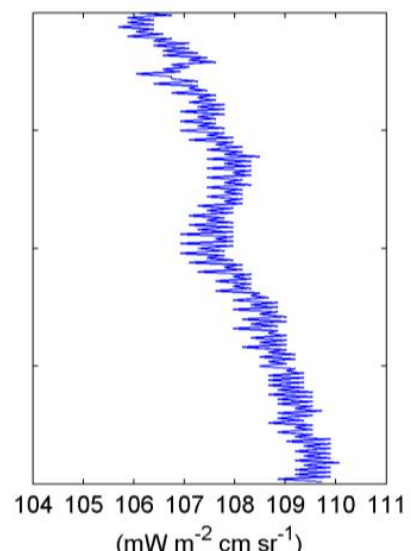

$\left(\mathrm{mW} \mathrm{m}^{-2} \mathrm{~cm} \mathrm{sr}^{-1}\right)$

COCTS $12 \mu \mathrm{m}$ channel corrected radiance

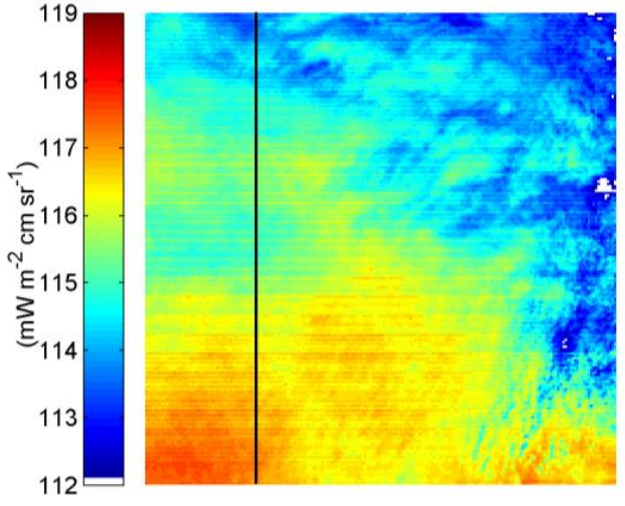

(b)

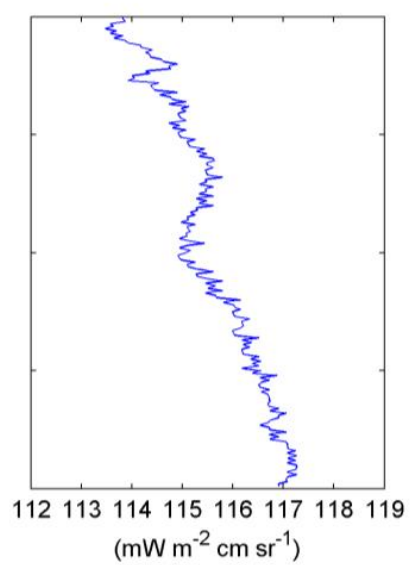

)

Figure 10. COCTS $12 \mu \mathrm{m}$ channel original and corrected regional radiance of $200 \times 200$ pixels size on 12 May 2011: (a) original radiance; and (b) corrected radiance. The blue plots in right panels indicate COCTS $12 \mu \mathrm{m}$ channel radiance variations along track at the location of black lines painted in left panels.

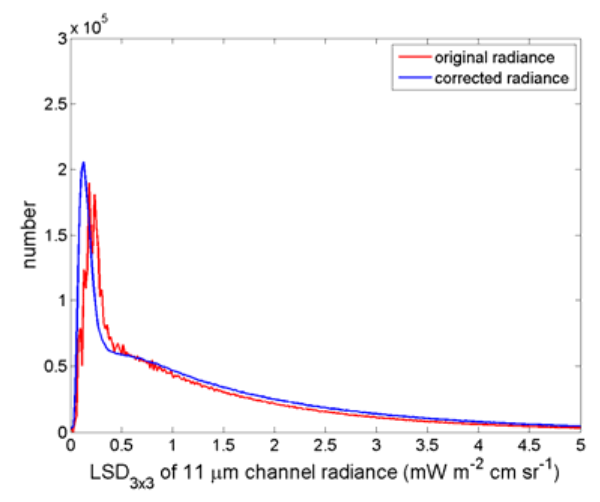

(a)

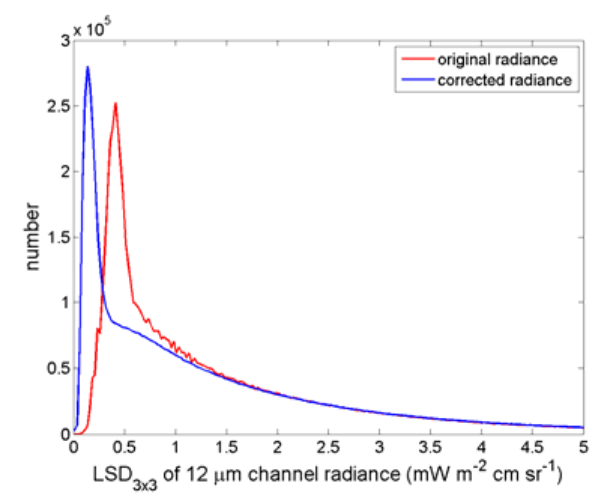

(b)

Figure 11. Histogram statistics of $\mathrm{LSD}_{3 \times 3}$ over radiance on 12 May 2011: (a) $11 \mu \mathrm{m}$ channel; and (b) channel $12 \mu \mathrm{m}$ channel. 


\section{Conclusions}

In this study, the COCTS radiances from thermal infrared channels were inter-calibrated with IASI in the northwest Pacific region during the period from 2009 to 2011. The comparison results indicate that the mean values of COCTS 11 and $12 \mu \mathrm{m}$ channel original radiance minus IASI radiance difference are $-6.35 \mathrm{~mW} \mathrm{~m}^{-2} \mathrm{~cm} \mathrm{sr}^{-1}$ and $-7.56 \mathrm{~mW} \mathrm{~m}^{-2} \mathrm{~cm} \mathrm{sr}^{-1}$, with the corresponding standard deviations of $0.96 \mathrm{~mW} \mathrm{~m}^{-2} \mathrm{~cm} \mathrm{sr}^{-1}$ and $0.63 \mathrm{~mW} \mathrm{~m}^{-2} \mathrm{~cm} \mathrm{sr}^{-1}$, respectively. The mean values of COCTS 11 and $12 \mu \mathrm{m}$ channel original BT minus IASI BT difference are $-4.08 \mathrm{~K}$ and $-4.75 \mathrm{~K}$, with the corresponding standard deviations of $0.50 \mathrm{~K}$ and $0.39 \mathrm{~K}$, respectively. In addition, the radiance difference between COCTS and IASI is radiance-dependent for both 11 and $12 \mu \mathrm{m}$ channel with a stronger dependence in the $11 \mu \mathrm{m}$ channel radiance difference with IASI radiance than $12 \mu \mathrm{m}$ channel. The time series plot of radiance difference demonstrates that there is no obvious time-dependent variation except a slight hopping at the junction point between March and April 2011.

The inter-calibration coefficients are obtained using linear robust regression for COCTS individual detectors separately. After correction, the mean values of COCTS minus IASI radiance difference are $-0.02 \mathrm{~mW} \mathrm{~m}^{-2} \mathrm{~cm} \mathrm{sr}^{-1}$ and $-0.01 \mathrm{~mW} \mathrm{~m}^{-2} \mathrm{~cm} \mathrm{sr}^{-1}$, respectively, with the corresponding standard deviations of $0.51 \mathrm{~mW} \mathrm{~m}^{-2} \mathrm{~cm} \mathrm{sr}^{-1}$ and $0.57 \mathrm{~mW} \mathrm{~m}^{-2} \mathrm{~cm} \mathrm{sr}^{-1}$. Both mean values of COCTS 11 and $12 \mu \mathrm{m}$ channel corrected BTs minus IASI are $-0.01 \mathrm{~K}$, with the corresponding standard deviations of $0.33 \mathrm{~K}$ and $0.35 \mathrm{~K}$, respectively. Compared with COCTS original radiance statistic results, the biases are removed and the standard deviations are reduced, and the dependence of radiance difference on IASI radiance is disappeared after correction. The significant striped noise of COCTS original radiance is reduced, which is evident in imagery and distributions of local standard deviation. In conclusion, several strands of evidence indicate the calibration accuracy of COCTS is improved after the correction. In a future study, the COCTS corrected radiance will be applied to SST retrieval in the expectation that this will improve the COCTS SST accuracy.

Author Contributions: M.L., C.J.M., L.G. and J.P.D.M. conceived and designed the experiments; M.L. processed and analysed the data and interpreted these jointly with C.J.M. and L.G.; M.L. wrote the paper; and C.J.M., L.G. and J.P.D.M. reviewed and edited the paper.

Funding: The work undertaken in this paper was funded by the Global Change Research Program of China (2015CB953901), the National Natural Science Foundation of China-Shandong Joint Fund for Marine Science Research Centers (U1606405), the National Natural Science Foundation of China (41376105), University of Reading (H5101900) and Chinese Scholarship Council.

Acknowledgments: HY-1B COCTS data were provided by SOA/NSOAS. MetOp-A IASI data were provided by EUMETSAT.

Conflicts of Interest: The authors declare no conflict of interest.

\section{References}

1. Chander, G.; Hewison, T.J.; Fox, N.; Wu, X.; Xiong, X.; Blackwell, W.J. Overview of intercalibration of satellite instruments. IEEE Trans. Geosci. Remote Sens. 2013, 51, 1056-1080. [CrossRef]

2. Rao, C.N.; Zhang, N.; Sullivan, J.T. Inter-calibration of meteorological satellite sensors in the visible and near-infrared. Adv. Space Res. 2001, 28, 3-10. [CrossRef]

3. Hewison, T.J.; Wu, X.; Yu, F.; Tahara, Y.; Hu, X.; Kim, D.; Koenig, M. GSICS inter-calibration of infrared channels of geostationary imagers using Metop/IASI. IEEE Trans. Geosci. Remote Sens. 2013, 51, 1160-1170. [CrossRef]

4. Pan, D. Future-generation satellites of Chinese ocean remote sensing. Sens. Syst. Next-Gener. Satell. VIII. 2004, 5570, 228-233. [CrossRef]

5. Guan, L.; Men, C. Sea Surface temperature from HY-1B COCTS. Proc. IEEE Geosci. Remote Sens. Symp. 2013, 652-655. [CrossRef]

6. IASI Level 1: Product Guide. 2017. Available online: https://www.eumetsat.int/website/wcm/idc/idcplg? IdcService=GET_FILE\&dDocName=PDF_DMT_151562\&RevisionSelectionMethod=LatestReleased\& Rendition=Web (accessed on 24 July 2018). 
7. Hilton, F.; Armante, R.; August, T.; Barnet, C.; Bouchard, A.; Camy-Peyret, C.; Capelle, V.; Clarisse, L.; Clerbaux, C.; Coheur, P.F.; et al. Hyperspectral Earth observation from IASI: Five years of accomplishments. Bull. Am. Meteorol. Soc. 2012, 93, 347-370. [CrossRef]

8. Blumstein, D.; Chalon, G.; Carlier, T.; Buil, C.; Hebert, P.; Maciaszek, T.; Ponce, G.; Phulpin, T.; Tournier, B.; Simeoni, D.; et al. IASI instrument: Technical overview and measured performances. Infrared Spaceborne Remote Sens. XII 2004, 5543, 196-208. [CrossRef]

9. Blumstein, D.; Tournier, B.; Cayla, F.R.; Phulpin, T.; Fjortoft, R.; Buil, C.; Ponce, G. In-flight performance of the Infrared Atmospheric Sounding Interferometer (IASI) on METOP-A. Atmos. Environ. Remote Sen. Data Process. Util. III Read. GEOSS 2007, 6684. [CrossRef]

10. Blumstein, D.; Pequignot, E.; Buffet, L.; Buil, C.; Hebert, P.; Larigauderie, C.; Phulpin, T.; Camy-Peyret, C.; Simeonii, D. The IASI Instrument. Available online: https:/ / www.ecmwf.int/sites/default/files/elibrary/ 2009/8249-iasi-instrument.pdf (accessed on 13 June 2018).

11. Wang, L.; Goldberg, M.; Wu, X.; Cao, C.; Iacovazzi, R.A.; Yu, F.; Li, Y. Consistency assessment of Atmospheric Infrared Sounder and Infrared Atmospheric Sounding Interferometer radiances: Double differences versus simultaneous nadir overpasses. J. Geophys. Res. Atmos. 2011, 116. [CrossRef]

12. Goldberg, M.; Ohring, G.; Butler, J.; Cao, C.; Datla, R.; Doelling, D.; Gärtner, V.; Hewison, T.; Iacovazzi, B.; Kim, D.; et al. The global space-based inter-calibration system. Bull. Am. Meteorol. Soc. 2011, 92, 467-475. [CrossRef]

13. Hewison, T.J. An evaluation of the uncertainty of the GSICS SEVIRI-IASI intercalibration products. IEEE Trans. Geosci. Remote Sens. 2013, 51, 1171-1181. [CrossRef]

14. Hu, X.; Xu, N.; Weng, F.; Zhang, Y.; Chen, L.; Zhang, P. Long-term monitoring and correction of FY-2 infrared channel calibration using AIRS and IASI. IEEE Trans. Geosci. Remote Sens. 2013, 51, 5008-5018. [CrossRef]

15. Wang, L.; Cao, C. On-orbit calibration assessment of AVHRR longwave channels on MetOp-A using IASI. IEEE Trans. Geosci. Remote Sens. 2008, 46, 4005-4013. [CrossRef]

16. Mittaz, J.; Harris, A. A physical method for the calibration of the AVHRR/3 thermal IR channels. Part II: An in-orbit comparison of the AVHRR longwave thermal IR channels on board MetOp-A with IASI. J. Atmos Ocean. Technol. 2011, 28, 1072-1087. [CrossRef]

17. Illingworth, S.M.; Remedios, J.J.; Parker, R.J. Intercomparison of integrated IASI and AATSR calibrated radiances at 11 and $12 \mu \mathrm{m}$. Atmos. Chem. Phys. 2009, 9, 6677-6683. [CrossRef]

18. Jiang, G.M.; Li, S.; Wang, Z.Y. Intercalibration of IRAS/FY-3B infrared channels with IASI/Metop-A 1C data. IEEE J. Sel. Top. Appl. Earth Obs. Remote Sens. 2017, 10, 2510-2517. [CrossRef]

19. Data Distribution Procedure. 2015. Available online: http://www.nsoas.gov.cn/portal/article/ 1420428121582.html\# (accessed on 12 July 2018).

20. IASI: Atmospheric Sounding Level 1C Data Products. NERC Earth Observation Data Centre. 2009. Available online: http:/ / catalogue.ceda.ac.uk/uuid/ea46600afc4559827f31dbfbb8894c2e (accessed on 9 July 2018).

21. Wu, X.; Hewison, T.; Tahara, Y. GSICS GEO-LEO intercalibration: Baseline algorithm and early results. Atmos. Environ. Remote Sens. Data Process. Util. V: Read. GEOSS III 2009, 7456. [CrossRef]

22. Bouali, M.; Ladjal, S. Toward optimal destriping of MODIS data using a unidirectional variational model. IEEE Trans. Geosci. Remote Sens. 2011, 49, 2924-2935. [CrossRef]

23. Bouali, M.; Ignatov, A. Estimation of detector biases in MODIS thermal emissive bands. IEEE Trans. Geosci. Remote Sens. 2013, 51, 4339-4348. [CrossRef]

24. Bouali, M.; Ignatov, A. Adaptive reduction of striping for improved sea surface temperature imagery from Suomi National Polar-Orbiting Partnership (S-NPP) visible infrared imaging radiometer suite (VIIRS). J. Atmos. Ocean. Technol. 2014, 31, 150-163. [CrossRef]

25. Liu, Q.; Cao, C.; Weng, F. Striping in the Suomi NPP VIIRS thermal bands through anisotropic surface reflection. J. Atmos. Ocean. Technol. 2013, 30, 2478-2487. [CrossRef]

(C) 2018 by the authors. Licensee MDPI, Basel, Switzerland. This article is an open access article distributed under the terms and conditions of the Creative Commons Attribution (CC BY) license (http:/ / creativecommons.org/licenses/by/4.0/). 